\title{
Selecting a New Water Heater
}

March 1995
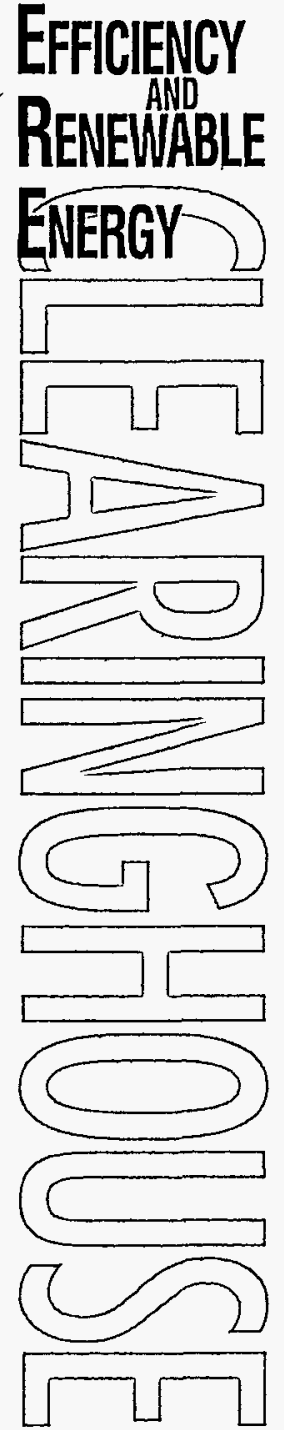

Many homeowners wait until their water heater fails before shopping for a replacement. Because they are in a hurry to regain their hot water supply, they are often unable to take the time to shop for the most energy-efficient unit for their specific needs. This is unfortunate, because the cost of purchasing and operating a water heater can vary greatly, depending on the type, brand, and model selected and on the quality of the installation.

To avoid this scenario, you might want to do some research now-before you are faced with an emergency purchase. Familiarize yourself today with the options that will allow you to make an informed decision when the need to buy a new waterheater arises.

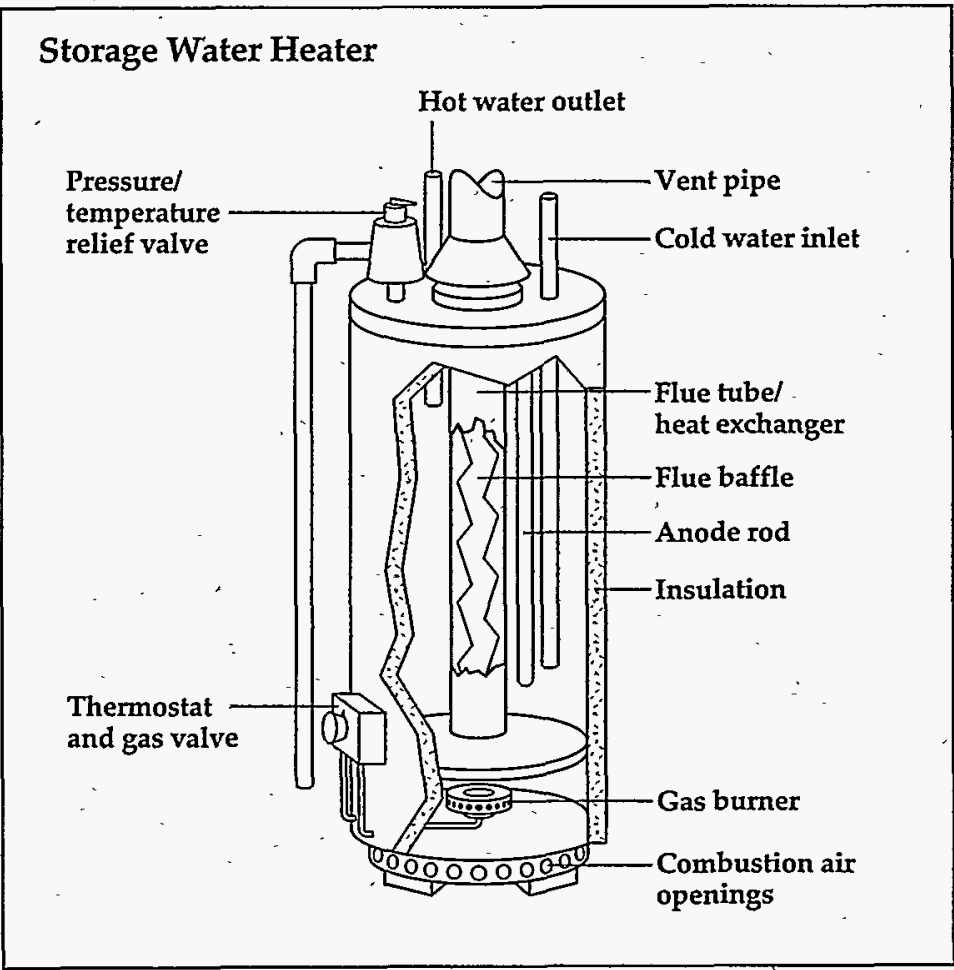

Storage water heaters remain the most frequently used type of water heater for residential purposes.

\section{Types of Water Heaters Available}

Within the last few years, a variety of water heaters have become available to consumers. The following types of water heaters are now on the market: conventional storage, demand, heat pump, tankless coil, indirect, and solar. It is also possible to purchase water heaters that can be connected to your home's spaceheating system.

\section{Storage Water Heaters}

A variety of fuel options are available for conventional storage water heaters-electricity, natural gas; oil, and propane. Ranging in size from 20 to 80 gallons ( 75.7 to 302.8 liters), storage water heaters remain the most popular type for residential heating needs in the United States. A storage heater operates by releasing hot water from the top of the tank when the hot water tap is turned on. To replace that hot water, cold water enters the bottom of the tank, ensuring that the tank is always full.

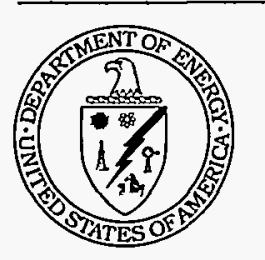

This document was produced for the U.S. Department of Energy (DOE) by the National Renewable Energy Laboratory (NREL), a DOE national laboratory. The document was produced by the Technical Information Program, under the DOE Office of Energy Efficiency and Renewable Energy. The Energy Efficiency and Renewable Energy Clearinghouse (EREC) is operated by NCI Information Systems, Inc., for NREL/DOE. The statements contained herein are based on information known to EREC and NREL at the time of printing. No recommendation or endorsement of any product or service is implied if mentioned by EREC. 


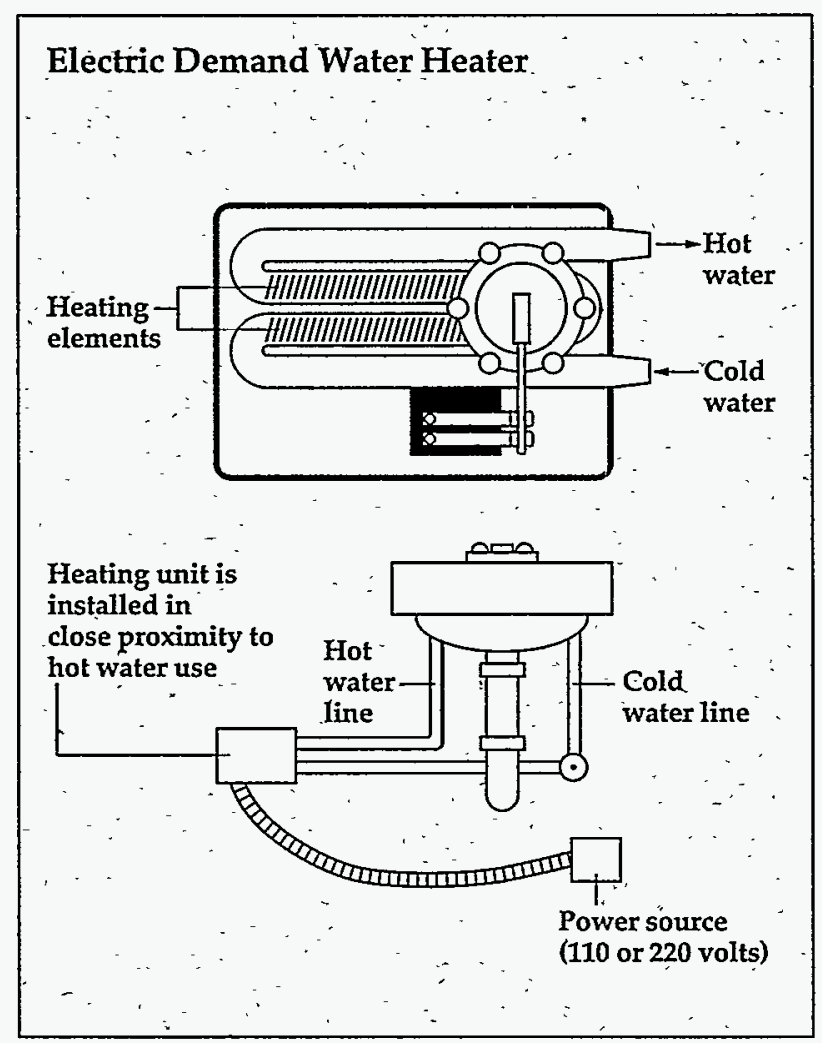

Because demand water heaters have no storage tanks, standby heat losses are completely eliminated.
Because the water is constantly heated in the tank, energy can be wasted even when no faucet is on. This is called standby heat loss. Newer, more energyefficient storage models can significantly reduce the amount of standby heat loss, making them much less expensive to operate. To determine the most energy-efficient model, consult the EnergyGuide label required on storage water heaters.

EnergyGuide labels indicate either the annual estimated cost of operating the system or energy efficiency ratings. with demand (or instantaneous) water heaters, which do not have storage tanks. Cold water travels through a pipe into the unit, and either a gas burner or an electric element heats the water only when needed. With these systems, you never run out of hot water. But there is one potential drawback with demand water heaterslimited flow rate.

Typically, demand heaters provide hot water at a rate of 2 to 4 gallons ( 7.6 to 15.2 liters) per minute. This flow rate might suffice if your household does not use hot water at more than one location at the same time (e.g., showering and doing laundry simultaneously). To meet hot water demand when multiple faucets are being used, demand heaters can be installed in parallel sequence. Although gas-fired demand heaters tend to have higher flow rates than electric ones, they can waste energy even when no water is being heated if their pilot lights stay on. However, the amount of energy consumed by a pilot light is quite small.

\section{Heat Pump Water Heaters}

Heat pump water heaters use electricity to move heat from one place to another instead of generating heat directly. To heat water for homes, heat pump water heaters work like refrigerators in reverse.

\section{Heat pump water}

heaters tend to cool

the spaces they are in, so they may need to be placed in isolated locations.

\section{Demand Water Heaters}

It is possible to completely eliminate standby heat losses from the tank and reduce energy consumption $20 \%$ to $30 \%$

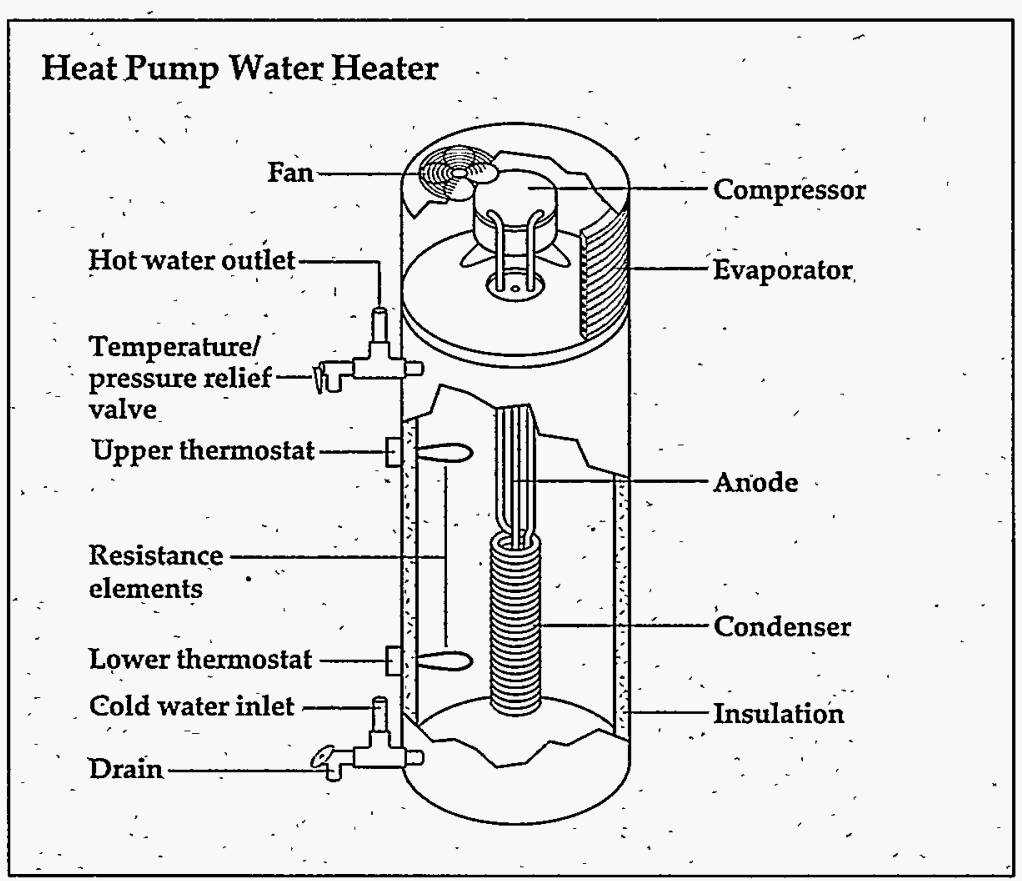

Although they can have a high initial cost, heat pump water heaters have the potential to reduce water-heating costs by as much as $50 \%$. 


\section{DISCLAIMER}

This report was prepared as an account of work sponsored by an agency of the United States Government. Neither the United States Government nor any agency thereof, nor any of their employees, make any warranty, express or implied, or assumes any legal liability or responsibility for the accuracy, completeness, or usefulness of any information, apparatus, product, or process disclosed, or represents that its use would not infringe privately owned rights. Reference herein to any specific commercial product, process, or service by trade name, trademark, manufacturer, or otherwise does not necessarily constitute or imply its endorsement, recommendation, or favoring by the United States Government or any agency thereof. The views and opinions of authors expressed herein do not necessarily state or reflect those of the United States Government or any agency thereof. 


\section{DISCLAIMER}

Portions of this document may be illegible in electronic image products. Images are produced from the best available original document. 
Tankless coil water

heaters work well.

during colder

months because

the heating system

is used regularly.
Heat pump water heaters can be purchased as integral units with built-in water storage tanks or as add-ons that can be retrofitted to an existing waterheater tank. These systems have a high initial cost. They also require installation in locations that remain in the $40^{\circ}$ to $90^{\circ} \mathrm{F}\left(4.4^{\circ}\right.$ to $\left.32.2^{\circ} \mathrm{C}\right)$ range year-round and contain at least 1000 cubic feet (28.3 cubic meters) of air space around the water heaters. To operate most efficiently, they should be placed in areas having excess heat, such as furnace rooms. They will not work well in a cold space.

\section{Tankless Coil and Indirect Water Heaters}

A home's space-heating system can also be used to heat water. Two types of water heaters that use this system are tankless coil and indirect. No separate storage tank

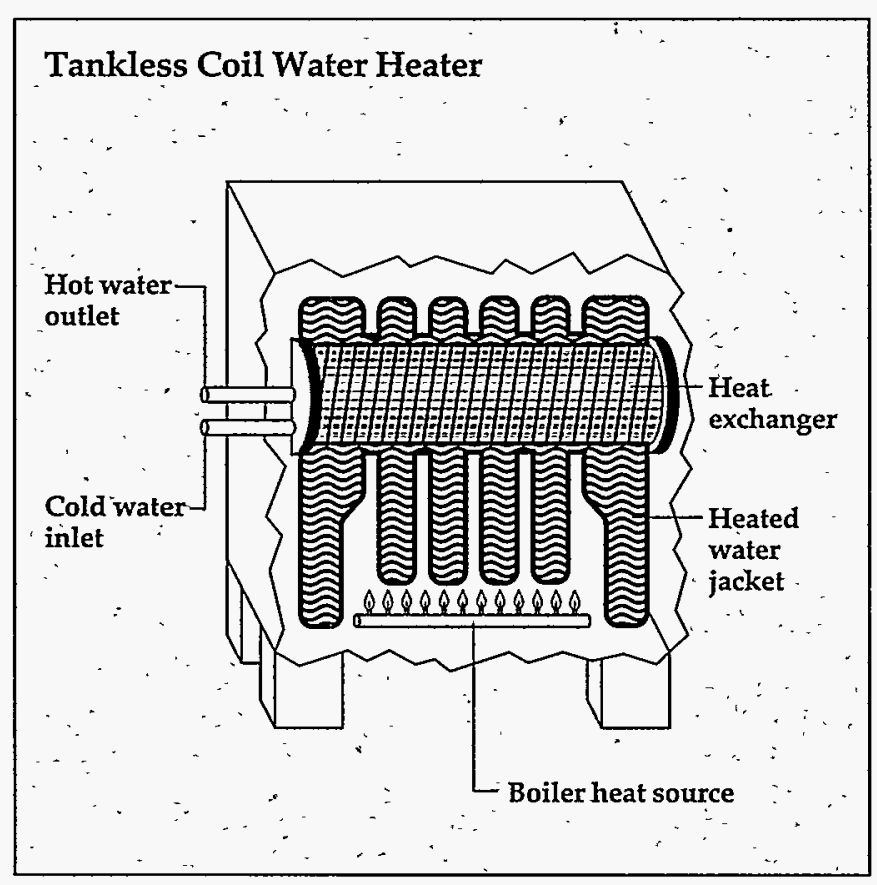

A tankless coil water heater uses a heat exchanger in the boiler to heat water.

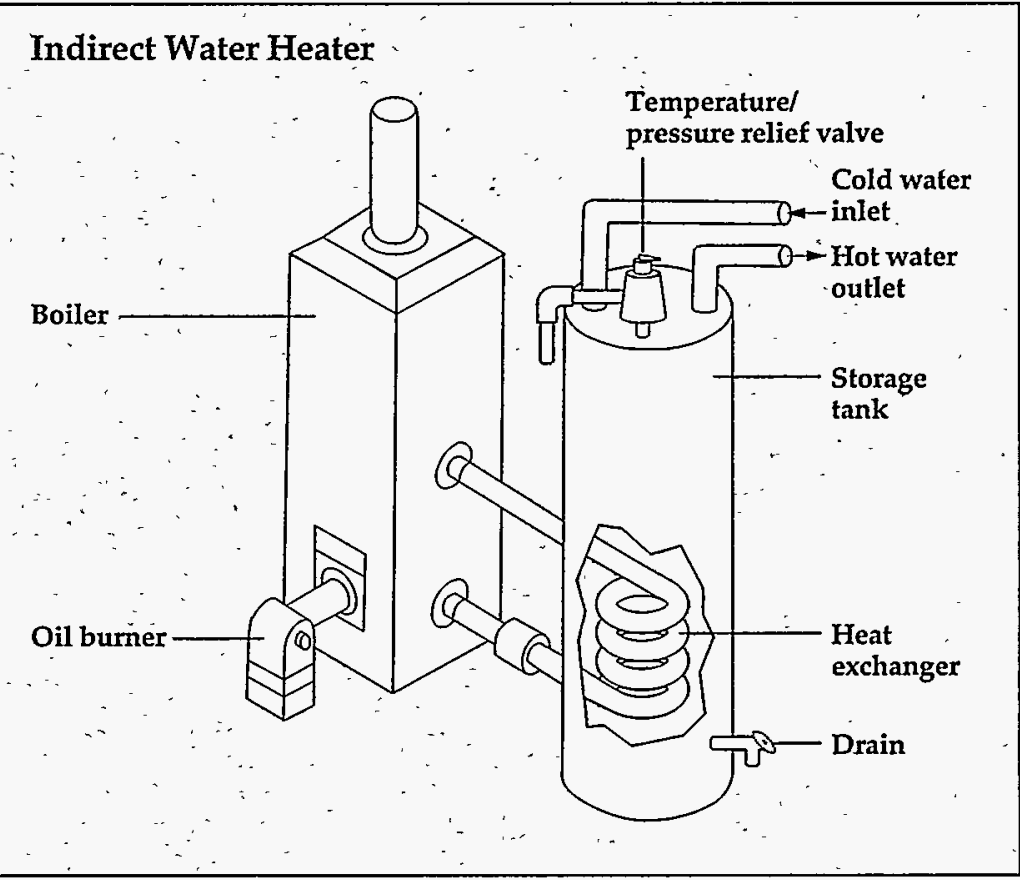

A combination of an indirect water heater and a highly efficient boiler can provide a very inexpensive method of water heating.

is needed in the tankless coil water heater because water is heated directly inside the boiler in a hydronic (i.e., hot water) heating system. The water flows through a heat exchanger in the boiler whenever a hot water faucet is turned on. During colder months, the tankless coil works well because the heating system is used regularly. However, the system is less efficient during warmer months and in warmer climates when the boiler is used less frequently.

A separate storage tank is required with an indirect water heater. Like the tankless coil, the indirect water heater circulates water through a heat exchanger in the boiler. But this heated water then flows to an insulated storage tank. Because the boiler does not need to operate frequently, this system is more efficient than the tankless coil. In fact, when an indirect water heater is used with a highly efficient boiler, the combination may provide one of the least expensive methods of water heating. 
Although the

purchase prices of

solar water heaters

are usually higher

than those of

conventional types,

operating costs are

much lower.

\section{Solar Water Heaters}

Through specially designed systems, energy from the sun can be used to heat water for your home. Depending on climate and water use, a properly designed, installed, and maintained solar water heater can meet from half to nearly all of a home's hot water demand.

Two features, a collector and a storage tank, characterize most solar water heaters. Beyond these common features, solar water-heating systems can vary significantly in design. The various system designs can be classified as passive or active and as direct (also called open loop) or indirect (also called closed loop).

Passive systems operate without pumps and controls and can be more reliable, more durable, easier to maintain, longer

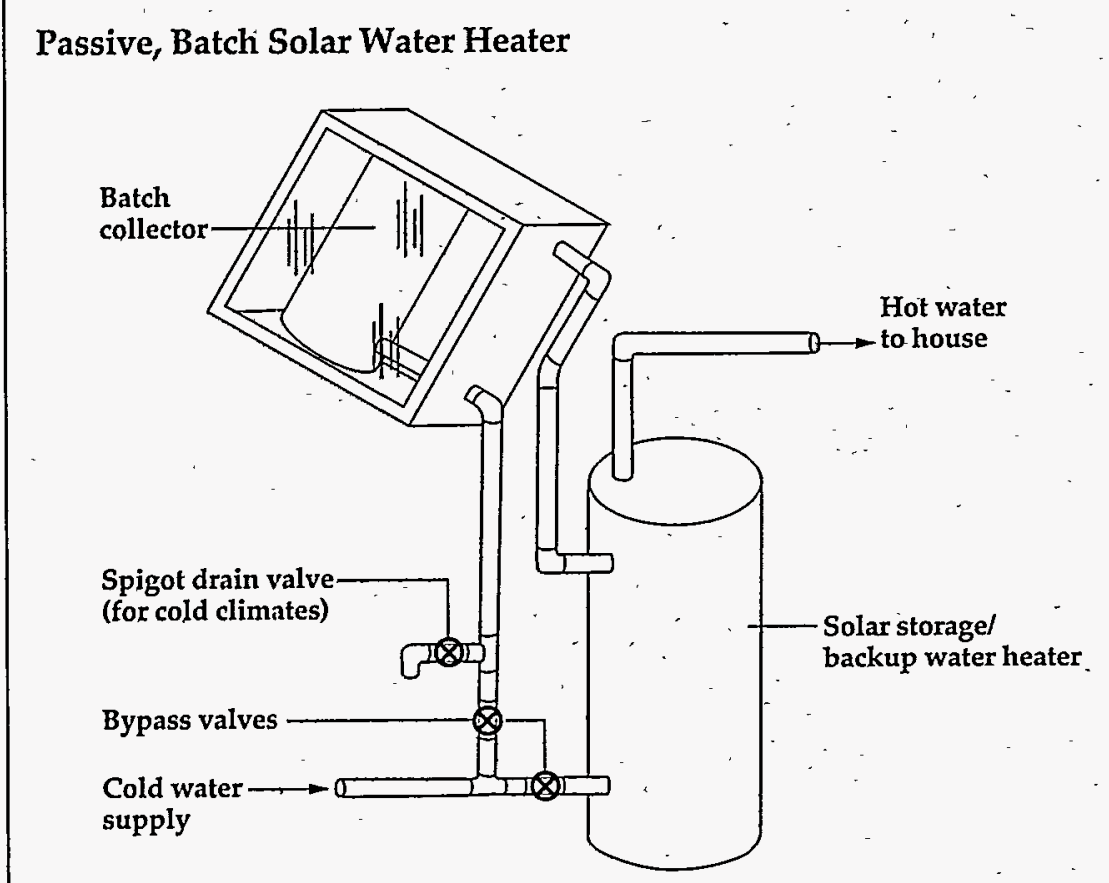

In a passive system, domestic water is heated in the solar collector, and transferred to the backup heater by the line pressure or thermosiphon action instead of by a pump. water heaters as backups, or the solar systems function as preheaters for the conventional units.

A direct solar wàter-heating system circulates household water through collectors and is not appropriate in climates in which freezing temperatures occur. An indirect system should not experience problems with freezing because the fluid in the collectors is usually a form of antifreeze.

If you are considering purchasing a solar water-heating system, you may want to compare-products from different manufacturèrs. The Solar Rating \& Certification Corporation (SRCC - see Source List at the end of this publication) provides a benchmark for comparing the performance of some solar water heating systems.

The SRCC publishes performance ratings of both solar water-heating systems and individual solar collectors. These published ratings are the results of independent, third-party laboratory testing of these products. All systems and collectors that have been certified by the SRCC will bear the SRCC label.

Keep in mind, though, that simply having an SRCC label does not imply that the product has a superior performance. Carefully compare SRCC label information on different brands and models to ensure that you are fully aware of projected performance.

The Florida Solar Energy Center (FSECsee Source List) also provides information on solar manufacturers and contractors. It also maintains solar equipment testing facilities and publishes performance ratings for solar water heating systems.

Just choosing a solar water heater with good ratings is not enough, though. Proper design, sizing, installation, and maintenance are also critical to ensure efficient system performance.

Although the purchase and installation prices of solar water heaters are usually higher than those of conventional types, operating costs are much lower.

For more information about solar waterheating systems, contact the Energy Efficiency and Renewable Energy Clearinghouse (EREC—-see Source List). 


\section{The least expensive}

\section{water heater to}

purchase may be

the most expensive

to operate.

\section{Criteria for Selection}

As with any purchase, balance the pros and cons of the different water heaters in light of your particular needs. There are numerous factors to consider when choosing a new water heater. This publication has already described different system configurations. Some other considerations are capacity, efficiency, and cost.

\section{Determining Capacity}

Although some consumers base their purchase on the size of the storage tank, the peak hour demand capacity, referred to as the first-hour rating (FHR) on the EnergyGuide label, is actually the more important figure. The FHR is a measure of how much hot water the heater will deliver during a busy hour, and it is required by law to appear on the unit's EnergyGuide label. Therefore, before you shop, estimate your household's peak hour demand and look for a unit with an FHR in that range.

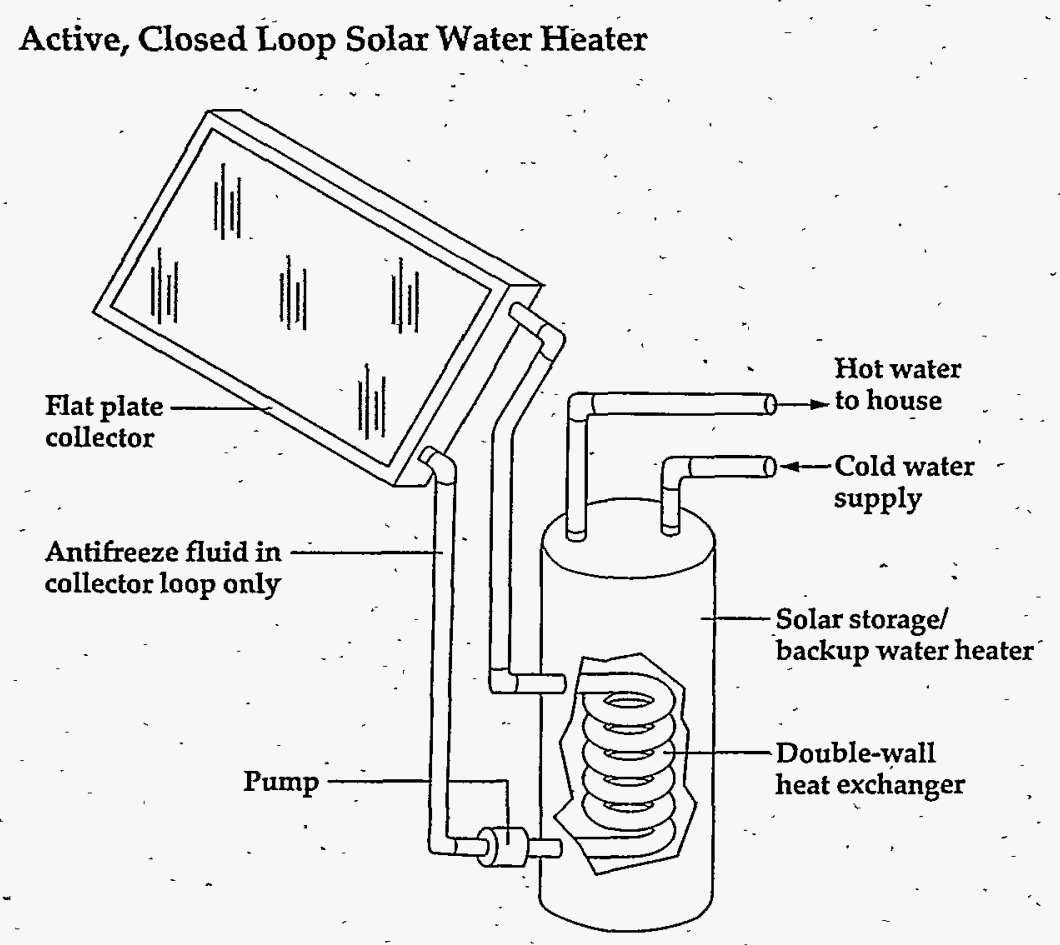

An active, closed loop system uses a heat exchanger to pass heat from the collector loop to the domestic water.

Gas water heaters have higher FHRs than electric water heaters of the same storage capacity. Therefore, it may be possible to meet your water-heating needs with a gas unit that has a smaller storage tank than an electric unit with the same FHR. More efficient gas water heaters use various nonconventional arrangements for combustion air intake and exhaust. These features, however, can increase installation costs.

\section{Rating Efficiency}

Once you have decided what type of water heater best suits your needs, determine which water heater in that category is the most fuel efficient. The best indicator of a heater's efficiency is its Energy Factor (EF), which is based on recovery efficiency (i.e., how efficiently the heat from the energy source is transferred to the water), standby losses (i.e., the percentage of heat lost per hour from the stored water compared to the heat content of the water), and cycling losses.

The higher the EF, the more efficient the water heater. Electric resistance water heaters have an EF between 0.7 and 0.95; gas heaters have an EF between 0.5 and 0.6 , with some high-efficiency models around 0.8 ; oil heaters range from 0.7 to 0.85 ; and heat pump water heaters range from 1.5 to 2.0 . Product literature from manufacturers usually gives the appliance's EF rating. If it does not, you can obtain it by contacting an appliance manufacturer association (see Source List).

Some other energy efficiency features to look for are tanks with at least 1.5 inches (3.8 centimeters) of foam insulation and energy efficiency ratings shown on the EnergyGuide labels.

\section{Comparing Costs}

Another factor uppermost in many consumers' minds is cost, which encompasses purchase price and lifetime maintenance and operation expenses.

When choosing among different models, it is wise to analyze the life-cycle cost-the total of all costs and benefits associated with a purchase during its estimated lifetime. More information on conducting lifecycle cost analyses is available from EREC.

Units with longer warranties usually have higher price tags, though. Often, the least expensive water heater to purchase is the most expensive to operate. 


\section{Source List}

The following organizations and publications provide more information on hot water energy efficiency. Much . of the information included in this publication was obtained from several of these sources. This list does not cover all the available books, reports, and articles on hot water energy efficiency, nor is the mention of any publication to be considered a recommendation or endorsement. To obtain the publications in this list, contact your local library or bookstore or the publisher. Check publication prices through your bookstore or the publisher before placing an order.

\section{American Council for an Energy-Efficient \\ Economy (ACEEE)}

1001 Connecticut Avenue, NW, Suite 801

Washington, DC 20036

(202) 429-8873

or

2140 Shattuck Avenue, Suite 202

Berkeley, CA 94704

ACEEE provides general and technical information on energy efficiency, including these publications: The Consumer Guide to Home Energy Savings, The Most Energy-Efficient Appliances, and Saving Energy and Money with Home Appliances. These publications can be ordered by writing the ACEEE office in Berkeley, California.

\section{Association of Home Appliance Manufacturers}

\section{(AHAM)}

Information Center

20 North Wacker Drive

Chicago, IL 60606

(312) 984-5800 ext. 315

AHAM provides energy efficiency information for specific brands of major appliances. The association also runs a certification program for certain types of appliances.

Florida Solar Energy Center (FSEC)

Attn: Public Information Office

300 State Road 401

Cape Canaveral, FL 32920

(407) 783-0300

FSEC is a state-supported solar research facility that answers questions on solar and other forms of renewable energy. FSEC provides free information and publications, including a quarterly newsletter, to the public.

\section{Gas Appliance Manufacturers Association, Inc.} (GAMA)

1901 North Moore Street, Suite 1100

Arlington, VA 22209

(703) 525-9565

GAMA has information on residential gas appliances and equipment, electric and oil-fired water heaters, and oil-fired warm air furnaces.
Solar Rating \& Certification Corporation (SRCC) 122 C Street, NW, 4th Floor

Washington, DC 20001

(202) 383-2570

SRCC is an independent, nonprofit organization that certifies and rates the performance of solar equipment and systems.

Further information about energy-efficient water heating can be obtained by contacting:

The Energy Efficiency and Renewable Energy

Clearinghouse (EREC)

P.O. Box 3048

Merrifield, VA 22116

(800) 363-3732

EREC provides free general and technical information to the public on a wide spectrum of topics and technologies pertaining to energy efficiency and renewable energy.

Also contact your state and local government energy offices as well as your utility for additional information on energyefficient water heaters, installation, and rebate or incentive programs.

\section{Reading List}

\section{Books and Reports}

Consumer Reports 1992 Buying Guide Issue, Consumers Union of the United States, Inc., 101 Truman Avenue, Yonkers, NY 10703, December'1991.

The. Water Heater Workbook: A Hands-on Guide to Water Heaters, published by Elemental Enterprises, P.O. Box 928, Monterey, CA 93942, 1992.

\section{Articles}

"Heat Pump Water Heaters in Hawaii-The Quiet Revolution," Plumbing Engineering, pp. 36-40, September 1994.

"Product Guide: Hot Water Heaters/Boilers," Energy User News, p. 28, January 1990.

"Safer Water Filters, Cheaper Water Heating Systems, and More," Home Mechanix, p. 37, June 1993.

"Solar.Hot Water for the 90s," Solar Today, p. 20, September 1991. 